DOI: 10.20472/IAC.2017.032.038

\author{
ABDULLAH SURUCU \\ Necmettin Erbakan University Ahmet Kelesoglu Education Faculty , Turkey
}

ESRA TEKE

Necmettin Erbakan University Institute of Social Sciences, Turkey

\title{
STUDENT PROBLEMS ACCORDING TO PARENTAL PERCEPTIONS: A CASE STUDY
}

\begin{abstract}
:
The purpose of this study is to identify the problems of pupils in a public primary school through the perceptions of their parents. An embedded multiple case study, one of the patterns of case studies was used in the study. The study was conducted on the parents of third and fourth year pupils in a primary school located in Selcuklu district of province of Konya in Turkey in the academic year 2016-2017. The "Problem Survey List for Children" developed by Owen (2008) was applied to the parents of a total of one hundred eighty-four pupils, including ninety-one girls and ninety-three boys in this study. The items most marked by the parents were dreaming during the day, unable to get started homework on time, feeling anger to the authority and wandering in the room. The items least marked were stealing, hitting other pupils in the classroom, and lying. As a result of the evaluation of the data, it was seen that the most and least marked items were the same in the third and fourth grades, and the other items showed similar characteristics in this direction. Individual interviews with pupils and parents was decided in order to understand the causes of the marked items and to help solve the problems. Additionally, organization of group guidance activities towards the problem areas and presentation / seminar work to solve issues were aimed. Strengthening cooperation between school and family and increasing the effectiveness in the studies by including the class teachers in the process were aimed in order for the study to be conducted to achieve the desired results.
\end{abstract}

\section{Keywords:}

Parents, student problems, case study

JEL Classification: 129 


\section{Introduction}

A problem survey list is used in psychological counseling and guidance in order to reveal the various problems of the individual. Problem Survey Inventories are the information gathering tools aimed at helping individuals and groups to solve their problems and identifying the extent of the problems related to the fields such as major sadness, needs, physical development, school, home, family, occupation, future, human relations, social values and attitudes and personality traits of individuals (Özgüven, 2007).

Thanks to the problem survey list, all problems that concern the individual and prevent him or her from creating a balanced and healthy collaboration with the environment can be identified. Psychological counseling and guidance assistance to be applied to the individual to provide solutions to the problems can be programmed (Alver, 2016). Problem survey lists are principally useful for the preparation and organization of school curricula and school guidance programs, recognition of the pupils and their interests, abilities, needs and problems by teachers, approaching the courses accordingly, helping them accordingly (mebk12, 2013).

The problem survey lists implemented by the guidance services in educational institutions have a great importance on identifying student problems. The problem areas of the students studying in the educational institution are handled in the light of statistical data and planning can be made for solving the identified problem areas within the framework of the results of the problem survey lists implemented. When we look at the studies conducted for this purpose (Zimmerman, Khoury, Vega, Gil, \& Warheit, 1995; Sadık, 2002; Sezer \& İşgör, 2010; Sezer, 2012 vb.) it is seen that different findings about the problems of the students who are studying at different educational levels were reached and there were identifications about the solutions of these problems.

A study by Sadık (2002) in Turkey in order to be determined the problem behaviors observed by $1 \mathrm{st}$ to 5 th grade primary school teachers in the class revealed that the most common problems encountered by the teachers were failing to complete the tasks, eating in the classroom, engaging in the inappropriate work, ... etc.). Behaviours such as stealing, using swearing words, lying, destroying the others' property were viewed as the most serious problems for the teachers. The study conducted on the pupils and students by Sezer and İşgör (2010) revealed that the schools of the pupils and students were physically inadequate, the families were repressive, they did not have enough communication with their parents, they were afraid of not being eligible to attend the university, they could not trust others, they expressed that the classes were very crowded and noisy, the most obvious personality problems of the pupils in the primary school were quick excitement, shyness and nervousness. When we look at the study by Sezer (2012), it was seen that a large number of pupils studying in the primary school marked the items on physical inadequacy of the school such as "our school is not clean, our course tools are not enough and sports facilities and activities are not enough". Other problems most frequently expressed by the pupils in the primary schools were "I am very nervous and the school administration and teachers are not understanding with me". 


\section{Purpose}

The purpose of this study is to identify the problems of pupils in a public primary school through the perceptions of their parents and to propose the solutions on which guidance services would be useful for solving these problems.

\section{Method}

Examining situational complexity is a vital part of social and behavioral science research. An embedded multiple case study, one of the patterns of case studies was used in the study (Yıldırım ve Şimşek, 2006). Qualitative case study methodology provides tools for researchers to study complex phenomena within their contexts (Baxter \& Jack, 2008). "The case" in the case study is the pupils studying in a public primary school.

\section{Study group}

The study was conducted on the parents of third and fourth year pupils in a primary school located in Selçuklu district of province of Konya in Turkey in the academic year 2016-2017. The "Problem Survey List for Children" was applied to the parents of a total of one hundred eighty-four pupils, including ninety-one girls and ninety-three boys in this study.

\section{Data Collection}

The data were obtained by the "Problem Survey List for Children" developed by Owen (2008). The "Problem Survey List for Children" is an easy to use checklist developed to provide a quick method for identifying problematic behaviors in children and provides the opportunity to identify developmental and behavioral problems of the primary school pupils that may occur in the present or future. The format of the checklist provides a structure and layout. Thus, both parents and teachers can easily and effectively identify problematic areas that may require psychological counseling intervention. The usage of such a tool makes it quick and easy to identify the problems experienced by the counselee, thus it can provide more effective usage of time in psychological counseling sessions. Parents and teachers included in the study. The stdy can be applied individually and / or in groups (Korkut-Owen, Owen ve Karaırmak, 2013).

\section{Data Analysis}

The data were obtained by applying the Problem Survey List for Children to the parents of the pupils in the $3 \mathrm{rd}$ and 4 th grade of the primary schools. Some of the practices were carried out in the school and some in the home environment. In the analysis of the data, the problems of children were tried to be determined by percentages.

\section{Findings}

The research findings were given in tabular form by combining 3rd grade, 4th grade and both grades. 


\section{The findings related to 3rd grade students:}

The Problem Survey List for Children was applied to the parents of a total of ninety pupils, including forty-eight girls and forty-two boys, from the third year of a primary school, and the resulting data were shown in the graphic below.

\section{Figure 1: The Results of Problem Survey List of 3rd Grades}

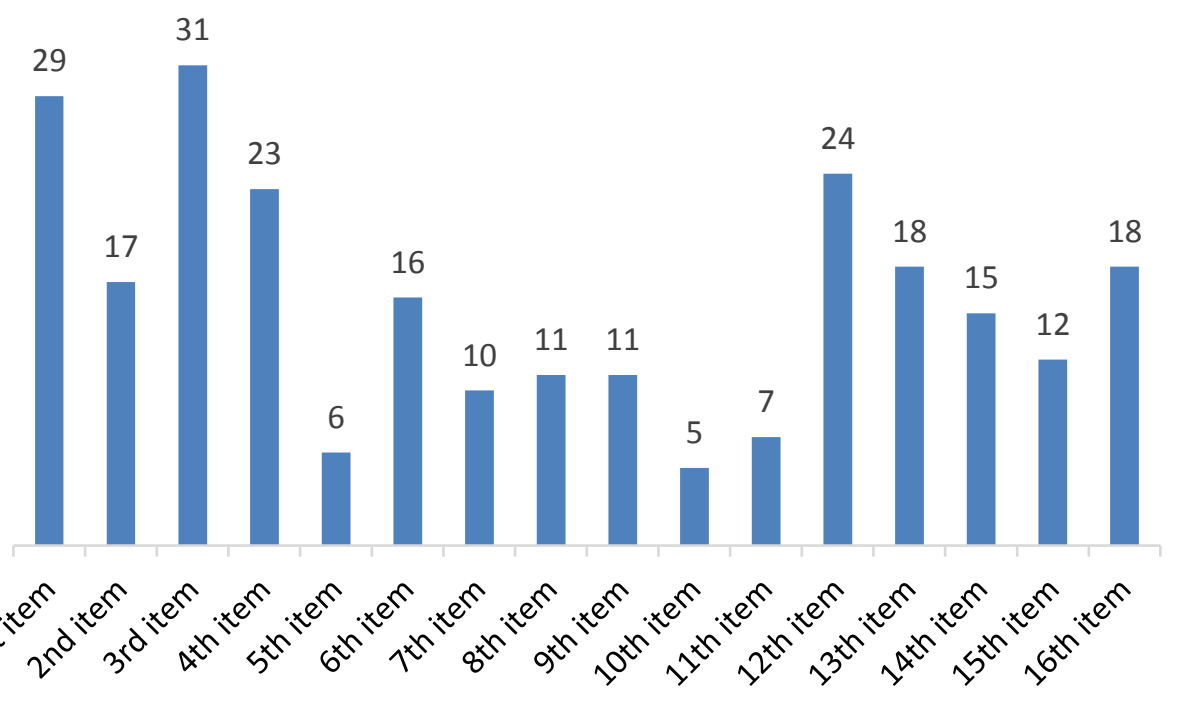

The parents marked the problematic items for the pupils on the checklists. Accordingly, 1 st item 29, 2nd item 17, 3rd item 31, 4th item 23, 5th item 6, 6th item 16, 7th item 10, 8th item 11,9 th item 11,10 th item 5,11 th item 7,12 th item 24,13 th item 18,14 th item 15,15 th item 12, 16th item 18 is a problem for the students.

The most marked items in the Problem Survey List for Children were 3rd item (dreaming during the day), 1 st item (unable to get started homework on time), 12th item (feeling anger to the authority) and 4th item (wandering in the room), respectively. The least marked items were 10th item (burgling), 5th item (hitting other pupils in the classroom) and 6th item (making noise to attract attention), respectively.

\section{The findings related to 4 th grade students:}

The Problem Survey List for Children was applied to the parents of a total of ninety four pupils, including forty-three girls and fifty-one boys, from the fourth year of a primary school, and the resulting data were shown in the graphic below. 
Figure 2: The Results of Problem Survey List of 4th Grades

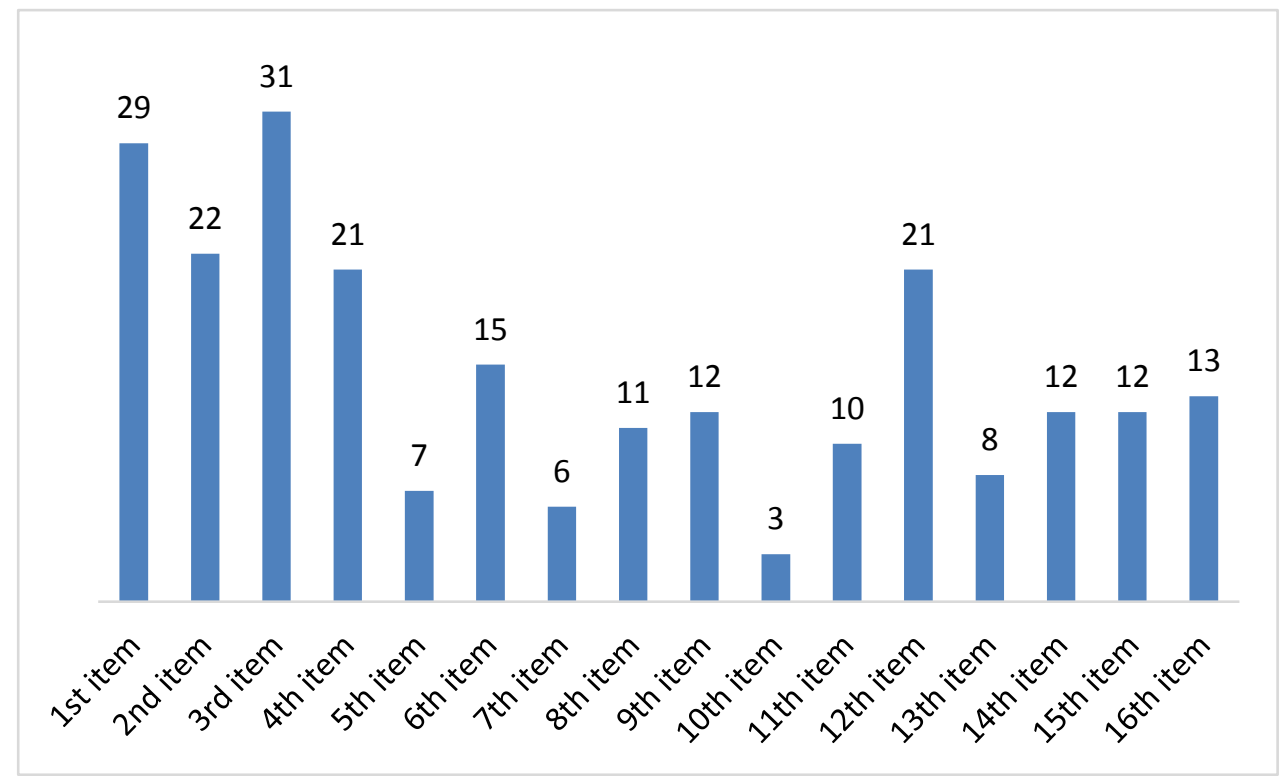

The parents marked the problematic items for the pupils on the checklists. Accordingly, 1st item 29, 2nd item 22, 3rd item 31, 4th item 21, 5th item 7, 6th item 15, 7th item 6, 8th item 11, 9th item 12, 10th item 3, 11th item 10, 12th item 21, 13th item 8, 14th item 12,15 th item 12, 16th item 13 is a problem for the students.

The most marked items in the Problem Survey List for Children were 3rd item (dreaming during the day), 1st item (unable to get started homework on time), 12th item (feeling anger to the authority) and 4th item (wandering in the room), respectively. The least marked items were 10th item (burgling), 7th item (hitting other pupils in the playground), 5th item (hitting other pupils in the classroom) and 13th item (not giving any response to the praise), respectively.

\section{General (3rd + 4th Grades) Findings:}

The effectiveness of Problem Survey List for Children was applied to the parents of the pupils from the third and fourth years of a primary school. The checklist was applied to the parents of a total of one hundred eighty-four pupils, including ninety-one girls and ninety-three boys. 
Figure 3: The Results of Problem Survey List of 3rd and 4th Grades

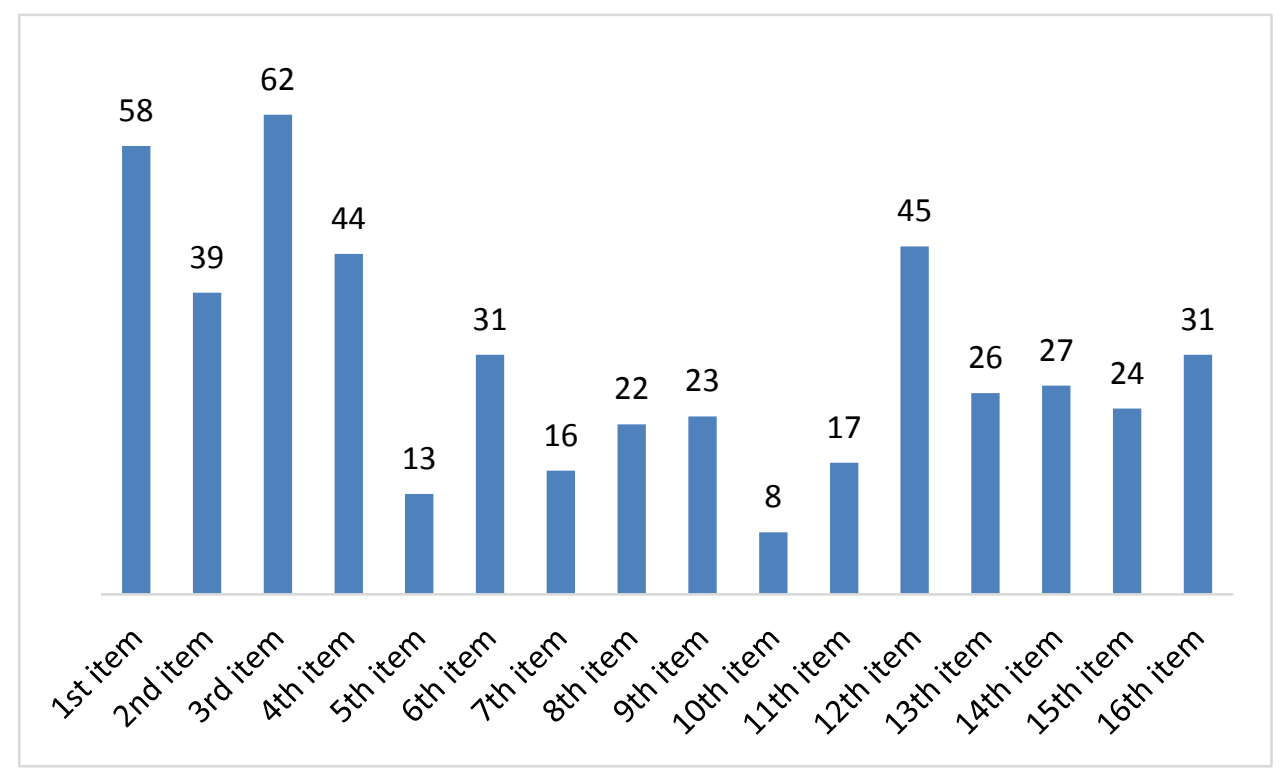

The parents marked the problematic items for the pupils on the checklists. Accordingly, 1 st item 58, 2nd item 39, 3rd item 62, 4th item 44, 5th item 13, 6th item 31, 7th item 16, 8th item 22, 9th item 23, 10th item 8, 11 th item 17, 12th item 45, 13th item 26, 14th item 27,15 th item 24,16 th item 21 is a problem for the students.

The most marked items in the Problem Survey List for Children were 3rd item (dreaming during the day), 1st item (unable to get started homework on time), 12 th (feeling anger to the authority) and 4th item (wandering in the room), respectively. The least marked items were 10th item (burgling), 5th item (hitting other pupils in the classroom) and 11th item (lying), respectively.

\section{Conclusion and Recommendation}

As a result of evaluating the checklists, it was seen that 3rd grade pupils' parents marked the items such as unable to get started homework on time, dreaming during the day, extraordinary shyness and introversion, depressive behaviors, etc. in relation to problem areas. On the other hand, it was seen that 4th grade pupils' parents marked the items such as unable to get started homework on time, dreaming during the day, feeling anger to the authority, etc.

The most marked items by the parents in the Problem Survey List for Children were dreaming during the day, unable to get started homework on time, feeling anger to the authority and wandering in the room, respectively. The least marked items were burgling, hitting other pupils in the classroom and lying, respectively.

As a result of evaluating the Problem Survey List for Children, it was observed that the most and least marked items were the same in the third and fourth grades, and the other items showed similar characteristics in this direction. 
Individual interviews with pupils and parents was decided in order to understand the causes of the marked items and to help solve the problems and when necessary, applying the test technique was decided in order to increase efficiency in the interviews and to achieve more objective results. Additionally, organization of group guidance activities towards the problem areas and presentation / seminar work to solve issues were aimed.

Strengthening cooperation between school and family and increasing the effectiveness in the studies by including the class teachers in the process were aimed in order for the study to be conducted to achieve the desired results.

It will be useful to do similar studies in other schools and compare the results. Similar studies can be conducted at different school and class levels.

\section{Reference}

ALVER, B. (2016). Bireyi tanıma teknikleri. C. Şahin (Ed.), Psikolojik danışma ve rehberlik (211-263). Ankara: Pegem Akademi.

BAXTER, P., \& JACK, S. (2008). Qualitative Case Study Methodology: Study Design and Implementation for Novice Researchers. The Qualitative Report, 13(4), 544-559. Retrieved from http://nsuworks.nova.edu/tqr/vol13/iss4/2

KORKUT-OWEN, F., OWEN, D.W. \& KARAIRMAK, Ö. (2013). Okul psikolojik danışmanları için el kitabı [Handbook for school psychological counselors]. Ankara: Anı.

mebk12. (2013). Problem tarama listesi. Retrieved from http://mebk12.meb.gov.tr/meb iys dosyalar/03/14/973965/dosyalar/2013 04/10041709 problem tarama.doc

ÖZGÜVEN, I.E. (2007). Bireyi tanıma teknikleri [Individual recognition techniques]. Ankara: PDREM.

SADIK, F. (2002). İlköğretim 1. Aşama sınıf öğretmenlerinin sınıfta gözlemledikleri problem davranışlar. Çukurova Üniversitesi Sosyal Bilimler Enstitüsü Dergisi, 10(10), 1-23.

SEZER, F. (2012). The Assessment of the problem areas of the students and solution recommendations. Turkish International Journal of Special Education and Guidance \& Counceling,1(2), 27-36.

SEZER, F. \& IŞGÖR I.Y. (2010). İlköğretim ve ortaöğretim kurumlarındaki öğrencilerin problem alanlarının tespiti [Identification of the problem areas of students in primary and secondary education institutions]. Millî Eğitim Dergisi, 39(186), 235-247.

STAKE, R.E. (2013). Multiple case study analysis. New York: The Guilford. Retrieved from https://books.google.com.

YILDIRIM, A., \& ŞiMŞEK, H. (2006). Sosyal bilimlerde nitel araştırma yöntemleri [Qualitative research methods in the social sciences]. Ankara: Seçkin.

ZIMMERMAN, R.S., KHOURY, E.L., VEGA, W.A., GIL, A.G., \& WARHEIT, G.J. (1995). Teacher and parent perceptions of behavior problems among a sample of African American, Hispanic, and nonHispanic white studients, American Journal of Community Psychology, 23(2), Version of Record online. 